\title{
Woody Plant Control in the Post Oak Savan- nah of Texas with Hexazinone
}

\section{C.J. SCIFRES}

\section{Abstract}

Hexazinone, applied as spheres or pellets $(1.27 \mathrm{~cm}$ in diameter) in grid patterns (1.5 or $3 \mathrm{~m}$ spacings) at 2 or $4 \mathrm{~kg} / \mathrm{ha}$ effectively controlled post oak and blackjack oak in east central Texas. The herbicide also appeared promising for control of water oak, American elm, and downy hawthorne. Willow baccharis and winged elm appeared to be moderately susceptible to $2 \mathrm{~kg} / \mathrm{ha}$ of the herbicide and were controlled by $4 \mathrm{~kg} / \mathrm{ha}$. Yaupon canopies were initially reduced by the herbicide but had begun to recover by the second or third growing season after application and replaced the oaks as the primary limitation to range improvement following treatment, regardless of hexazinone rate applied. Saw greenbrier, mustang grape, southern dewberry, American beautyberry, and woollybucket bumelia were not controlled by hexazinone.

The Post Oak Savannah occupies about 3.4 million hectares of gently rolling to hilly lands in east central Texas (Gould 1969). The grasslands of the Post Oak Savannah are well suited to livestock production, and optimum use for much of the area is as range if improved and properly managed (Scifres 1980).

Much of the Post Oak Savannah has been converted from true savannah to heavy thickets to woody plants, persumably the results of long-term overgrazing and the restriction of naturallyoccurring fires. Large post oak (Quercus stellata) and blackjack oak (Quercus marilandica) trees usually form the overstory above almost impenetrable thickets of yaupon (Ilex vomitoria), winged elm (Ulmus alata), woollybucket bumelia (Bumelia lanuginosa), downy hawthorne (Crategus mollis), spiny hackberry (Celtis pallida), common honeylocust (Gleditsia triacanthos), buckbrush (Symphroicarpos orbiculatus), tree huckleberry (Vaccinium arboreum) and other shrubs.

The woody canopy of thicketized Post Oak Savannah restricts the growth of grasses except for the most shade-tolerant species such as low-growing dichantheliums (Dichanthelium spp.) and longleaf chasmanthium (Chasmanthium latifolium). Soils of the Post Oak Savannah, typically fine sandy loams to loamy sands $\mathbf{2 0}$ to $70 \mathrm{~cm}$ thick over a claypan, a re capable of supporting productive stands of grasses such as little bluestem(Schizachyrium scoparium var. frequens), Indiangrass (Sorghastrum nutans), switchgrass (Panicum virgatum), purpletop (Tridens flavus), and silver blue-

\footnotetext{
Author is professor, Department of Range Science (Texas Agricultural Experiment Station), Texas A\&M University, College Station, 77801. Published with approval of the Director, Texas Agricultural Experiment Station as TA-16234. The author is grateful to Julia Scifres for manuscript typing and preparation.
}

stem (Bothriochloa saccharoides) if effective brush management is practiced (Scifres and Haas 1974). However, costs of mechanical brush control methods usually restrict their application to complete conversion of these sites to tame pastures or cropland. Broadcast application of a mixture of 2,4,5-T[(2,4,5-trichlorophenoxy)acetic acid] and picloram (3,5,6-trichloropicolinic acid) effectively controls many of the woody species in the mixed-brush stands (Scifres and Haas 1974) but the proximity of herbicidesusceptible crops and vegetables seriously limits the use of aeria sprays in the region (Scifres 1980). Therefore, recent research interest has focused upon the development of dry herbicide formulations which minimize the potential of herbicide damage to adjacent, nontarget plants.

Hexazinone [2-cyclohexy-6-(dimethylamino)-1-methyl-1,3,5triazine-2,4 (1H, 3H-dione)] has shown promise for controlling several woody species on rangeland (Scifres and Mutz 1978), especially when applied as pellets $(3.2 \mathrm{~mm}$ in diameter) in rows $1.8 \mathrm{~m}$ apart rather than broadcast (Meyer and Bovey 1980). Hexazinone is also applied as relatively large $(1.27 \mathrm{~cm}$ diameter $)$ spheres, and at wide but regular spacings so that herbaceous vegetation is damaged only in small, localized areas. This "grid placement" of herbicide has been used for applying karbutilate [tert-butylcarbamic acid ester with 3 ( $m$-hydroxyphenyl)-1,1-dimethylurea] to achieve selective brush control (Scifres et al. 1978). The objective of this research was to evaluate the efficacy of hexazinone applied as relatively large spheres or pellets by grid placement for control of several woody species common to the Post Oak Savannah.

\section{Materials and Methods}

Hexazinone was formulated as compressed spheres or extruded pellets, $1.27 \mathrm{~cm}$ in diameter and containing $15 \%$ active ingredient A random sample of 100 particles was weighed, and the grid spacings were calculated to achieve selected application rates.

One experiment was installed on the Texas A\&M University Range Research Area near College Station on March 24, 1976. Soil was of the Lufkin-Tabor series (Udertic Paleustalfs). The area supported a relatively open stand of post oak and blackjack oak in association with winged elm, woollybucket bumelia, water oak (Quercus nigra) and lesser amounts of various other woody species. The herbaceous understory was dominated by low-growing dichantheliums, brownseed paspalum (Paspalum plicatulum) and various forbs. Plots were $30-$ by $30-\mathrm{m}$ in size and separated by 
Table 1. Canopy reduction (\%) of post and blackjack oaks at various times after application of hexizone in grid patters on March 24, 1976, near College Station.

\begin{tabular}{|c|c|c|c|c|c|c|c|c|c|c|c|}
\hline \multirow{3}{*}{$\begin{array}{l}\text { Application } \\
\text { rate } \\
\text { (kg/ha) }\end{array}$} & \multirow{3}{*}{$\begin{array}{l}\text { Pellet } \\
\text { spacing } \\
\quad(\mathrm{m})\end{array}$} & \multicolumn{10}{|c|}{ Months after treatment ${ }^{1}$} \\
\hline & & \multicolumn{5}{|c|}{ Blackjack oak } & \multicolumn{5}{|c|}{ Post oak } \\
\hline & & 6 & 17 & 27 & 40 & 50 & 6 & 17 & 27 & 40 & 50 \\
\hline $\begin{array}{c}0.5 \\
1 \\
2 \\
2 \\
4\end{array}$ & $\begin{array}{c}3 \\
3 \\
1.5 \\
3 \\
1.5\end{array}$ & $\begin{array}{l}0 \mathrm{a} \\
36 \mathrm{c} \\
78 \mathrm{efg} \\
70 \mathrm{e} \\
80 \mathrm{e}-\mathrm{h}\end{array}$ & $\begin{array}{c}0 \mathrm{a} \\
50 \mathrm{~d} \\
94 \mathrm{ghi} \\
100 \mathrm{i} \\
100 \mathrm{i}\end{array}$ & $\begin{array}{c}0 \mathrm{a} \\
0 \mathrm{a} \\
88 \mathrm{e}-\mathrm{i} \\
100 \mathrm{i} \\
100 \mathrm{i}\end{array}$ & $\begin{array}{r}3 \mathrm{ab} \\
5 \mathrm{ab} \\
90 \mathrm{e}-\mathrm{i} \\
100 \mathrm{i} \\
100 \mathrm{i}\end{array}$ & $\begin{array}{c}0 \mathrm{a} \\
0 \mathrm{a} \\
88 \mathrm{e}-\mathrm{i} \\
97 \mathrm{ghi} \\
99 \mathrm{hi}\end{array}$ & $\begin{array}{l}0 \mathrm{a} \\
70 \mathrm{e} \\
94 \mathrm{ghi} \\
95 \mathrm{ghi} \\
99 \mathrm{hi}\end{array}$ & $\begin{array}{c}0 \mathrm{a} \\
50 \mathrm{~d} \\
82 \mathrm{e}-\mathrm{i} \\
88 \mathrm{e}-\mathrm{i} \\
100 \mathrm{i}\end{array}$ & $\begin{array}{l}0 \mathrm{a} \\
46 \mathrm{~d} \\
73 \mathrm{ef} \\
85 \mathrm{e}-\mathrm{i} \\
97 \mathrm{ghi}\end{array}$ & $\begin{array}{l}14 \mathrm{ab} \\
16 \mathrm{abc} \\
75 \mathrm{ef} \\
89 \mathrm{e}-\mathrm{i} \\
100 \mathrm{i}\end{array}$ & $\begin{array}{c}0 \mathrm{a} \\
20 \mathrm{bc} \\
78 \mathrm{efg} \\
95 \mathrm{ghi} \\
99 \mathrm{hi}\end{array}$ \\
\hline
\end{tabular}

'Means followed by the same letter are not significant at the $95 \%$ level according to Tukey's $w$-procedure. Mean value for species in untreated plots were $0 \mathrm{a}$ for all evaluation dates.

16-m-wide untreated strips. Hexazinone was hand applied on approximately 1.5 or 3-m grid spacings to achieve application rates of $0,0.5,1,2$, or $4 \mathrm{~kg} / \mathrm{ha}$. Each treatment (herbicide rate-grid spacing) was applied to triplicate plots in a randomized complete block design.

A second experiment was installed near Marquez, about $80 \mathrm{~km}$ north of College Station, on May 12 and 13, 1977. The soil was of the Axtell-Tabor series, similar to that of the site near College Station. The site near Marquez supported a heavy stand of large post oaks and blackjack oak in association with black history (Carya texana), American beautyberry (Callicarpa americana), tree huckleberry, American elm (Ulmus americana), and yaupon. The herbaceous cover consisted of scattered plants of longleaf chasmanthium and dichantheliums. Hexazinone particles were applied on approximately 1,2, or 3-m spacings to result in application rates of $0.6,1.2,2.6$, and $5 \mathrm{~kg} /$ ha (active ingredient). Each treatment, including untreated checks, was replicated three times on 31 by $31-\mathrm{m}$ plots which were separated by $16-\mathrm{m}$ untreated strips, and the experiment was arranged in a randomized complete block design.

At $6,17,27,40$, and 50 months after hexazinone application near College Station, the percentage defoliation of each woody plant in each plot was estimated by two workers. Estimates were averaged by species and dates and subjected to hierarchal analysis of variance to allow expressing the influence of time after hexazinone application on treatment effectiveness. Because of the range of percentages, data transformation prior to analysis of variance did not influence results (Steel and Torrie 1960). At 18 and 27 months after treatment, standing crop of herbaceous species was harvested from five, equidistantly-spaced, $0.25 \mathrm{~m}^{2}$ sampling a reas across each plot. The standing crop was separated into grasses and forbs, dried at $60^{\circ} \mathrm{C}$ for 24 hours, and weighed. At 12 and 18 months after herbicide application, ten, 10-point frame samples were taken on a diagonal across each plot. At 12 and 24 months after treatment, the diameter of bare areas at the point of herbicide placement was measured at 10 locations in each plot.

The response of woody plants in the experiment near Marquez was evaluated at $6,14,26$, and 36 months after treatment. Forage standing crop and herbaceous foliar cover were evaluated at the same time as described for the experiment near College Station.

Triplicate soil samples were recovered at depths of 0 to 3,3 to 8,8 to 15,15 to 30,30 to 45 , and 45 to $90 \mathrm{~cm}$ from two randomly selected locations in each plot. Textural components of the soils were determined by the hydrometer method (Milford 1975), pH of a 1:2 slurry (Peech 1965), and organic matter content by acid digestion and titration (Mortensen 1965).

\section{Results}

Soil properties of the study site near College Station varied little with depth to $30 \mathrm{~cm}$. Sand content averaged $53 \%$, clay content averaged $12 \%$, and $\mathrm{pH}$ was 5.1 . From 30 to $90 \mathrm{~cm}$ deep, sand content averaged $26 \%$, clay content averaged $39 \%$, and $\mathrm{pH}$ was 6.3 . Organic matter content was uniformly low, varying from 0.7 to $0.8 \%$, regardless of depth. About $5 \mathrm{~cm}$ of rainfall, adequate to dissolve the herbicide particles, were received within 2 weeks after hexazinone application near College Station, and $22 \mathrm{~cm}$ of rainfall were received during the first 6 months after herbicide application. By the fall of 1977 , after hexazinone application during the spring 1976 , more than $100 \mathrm{~cm}$ of rainfall had occurred on the study area.

Hexazinone at $0.5 \mathrm{~kg} /$ ha did not significantly reduce the canopies of post oak or blackjack oak, regardless of evaluation date (Table 1). However, application of $1 \mathrm{~kg} /$ ha of hexazinone initially improved control of both oak species, based on canopy reduction. Canopy reduction of blackjack oak was $50 \%$ at 17 months after treatment, but the canopy had recovered at 27 months after application of $1 \mathrm{~kg} / \mathrm{ha}$. Post oak initially appeared to be more susceptible to $1 \mathrm{~kg} / \mathrm{ha}$ of hexazinone than did blackjack oak, but defoliation of post oak was $20 \%$ or less at 40 and 50 months after herbicide application.

Where $2 \mathrm{~kg} /$ ha of hexazinone were applied near College Station, canopy reduction of post and blackjack oaks did not differ significantly, regardless of 1.5 or 3-m grid spacing (Table 1). However, there was a tendency for $2 \mathrm{~kg} / \mathrm{ha}$ of the herbicide applied on $1.5-\mathrm{m}$ spacings to be less effective than the same rate with the pellets applied in a $2-\mathrm{m}$ grid. There was no obvious explanation for this trend but Meyer and Bovey (1980) also reported that localizing hexazinone, in rows compared to broadcast applications in their study, improved control of several woody species. Hexazinone at 4 $\mathrm{kg}$ / ha effective controlled both species of oaks after the first growing season near College Station.

Woollybucket bumelia was less susceptible to hexazinone than

Table 2. Canopy reduction (\%) of woollybucket bumelia and winged elm at various times after application of hexazinone in grid patterns on March 24, 1976, near College Station, Texas.

\begin{tabular}{|c|c|c|c|c|c|c|c|c|c|c|c|}
\hline \multirow{3}{*}{$\begin{array}{l}\text { Application } \\
\text { rate } \\
(\mathrm{kg} / \mathrm{ha})\end{array}$} & \multirow{3}{*}{$\begin{array}{l}\text { Pellet } \\
\text { spacing } \\
\text { (m) }\end{array}$} & \multicolumn{10}{|c|}{ Months after treatment 1} \\
\hline & & \multicolumn{5}{|c|}{ Woollybucket bumelia } & \multicolumn{5}{|c|}{ Winged elm } \\
\hline & & 6 & 17 & 27 & 40 & 50 & 6 & 17 & 27 & 40 & 50 \\
\hline 0.5 & 3 & $25 \mathrm{de}$ & $0 \mathrm{a}$ & $0 \mathrm{a}$ & $0 \mathrm{a}$ & $0 \mathrm{a}$ & $81 \mathrm{j}-\mathrm{m}$ & 22 b-e & $0 \mathrm{a}$ & $0 \mathrm{a}$ & $0 \mathrm{a}$ \\
\hline 1 & 3 & $47 \mathrm{fg}$ & $13 a-d$ & $0 \mathrm{a}$ & $1 \mathrm{a}$ & $0 \mathrm{a}$ & $96 \mathrm{mn}$ & $70 \mathrm{ijk}$ & 63 ghi & $27 \mathrm{de}$ & $25 \mathrm{de}$ \\
\hline 2 & 1.5 & $71 \mathrm{ijk}$ & 36 ef & $7 a b c$ & 13 a-d & $0 \mathrm{a}$ & $100 n$ & $91 \mathrm{lmj}$ & $93 \mathrm{mn}$ & $71 \mathrm{ijk}$ & $47 \mathrm{fg}$ \\
\hline 2 & 3 & $74 \mathrm{i}-1$ & $49 \mathrm{fgh}$ & $6 \mathrm{ab}$ & $7 \mathrm{abc}$ & $5 \mathrm{ab}$ & $100 n$ & $100 n$ & $92 \mathrm{mn}$ & 60 ghi & $79 \mathrm{j}-\mathrm{m}$ \\
\hline 4 & 1.5 & $86 k-n$ & $66 \mathrm{hij}$ & 24 cde & $14 a-d$ & $25 \mathrm{de}$ & $100 n$ & $99 n$ & $99 n$ & $100 \mathrm{n}$ & $99 n$ \\
\hline
\end{tabular}

IMeans followed by the same letter are not significantly different at the $95 \%$ level according to Tukey's $w$-procedure. Mean values for species in untreated plots were 0 a for all evaluation dates. 
post oak and blackjack oak at College Station. By 27 months after hexazinone application, canopies of woollybucket bumelia were significantly reduced only where $4 \mathrm{~kg}$ / ha were applied (Table 2). At 50 months after hexazinone application, the woollybucket bumelia had completely recovered except where $4 \mathrm{~kg} / \mathrm{ha}$ were applied, and canopy reduction following application of the highest rate was only $25 \%$.

Defoliation of winged elm during the season of application near College Station was about $80 \%$ where $0.5 \mathrm{~kg} /$ ha of hexazinone was applied, and $96 \%$ to $100 \%$ on plots receiving $1 \mathrm{~kg} /$ ha or more of the herbicide (Table 2). However, the winged elm had recovered from effects of the $0.5 \mathrm{~kg}$ / ha rate by 27 months after hexazinone application, and canopy reduction was only $27 \%$ at 40 months after application of $1 \mathrm{~kg} /$ ha of the herbicide. Winged elm control was improved when 2 or $4 \mathrm{~kg} /$ ha of hexazinone were applied, compared to that from the lower rates. Grid spacing to achieve the 2 $\mathrm{kg} /$ ha rate had no apparent influence on canopy reduction of winged elm, except after 50 months when the 3-m spacing appeared to be more effective than the 1.5-m spacing.

Saw greenbrier (Smilax bona-nox) tolerated the rates of hexazinone applied near College Station (data not shown). Although saw greenbrier leaf margins were necrotic the season of application of 1 $\mathrm{kg}$ / ha or more of hexazinone, canopy reduction was only about $40 \%$ at 17 months after application of 2 or $4 \mathrm{~kg} /$ ha of the herbicide. By 27 months after application of the higher rates, saw greenbrier had fully recovered from the effects of the herbicide, regardless of application rate. These results are similar to those of Meyer and Bovey (1980).

Although not present in adequate quantities for detailed evaluation, water oak and downy hawthorne appeared to be susceptible (canopy reduction $>90 \%$ ) to $2 \mathrm{~kg} /$ ha of hexazinone. Yaupon and willow baccharis (Baccharis salicina) appeared to be only moderately susceptible (canopy reduction $\leq 60 \%$ ) to $2 \mathrm{~kg} /$ ha in the experiment near College Station, and mustang grape (Vitis mustangensis) and southern dewberry (Rubus trivialis) appeared to be relatively tolerant (canopy reduction $<25 \%$ ) of $2 \mathrm{~kg} /$ ha or less

Table 3. Canopy reduction (\%) of several wood species at 14,26 , and 36 months after application of hexazinone in grid patterns in May 1977 near Marquez, Texas.

\begin{tabular}{|c|c|c|c|c|}
\hline \multirow[b]{3}{*}{ Species } & \multicolumn{4}{|c|}{ Hexazinone spacing $(\mathrm{m})$ and rate $(\mathrm{kg} / \mathrm{ha})^{1}$} \\
\hline & \multirow{2}{*}{$\frac{3 \mathrm{~m}}{0.6}$} & \multicolumn{2}{|c|}{$2 \mathrm{~m}$} & \multirow{2}{*}{$\frac{1 \mathrm{~m}}{5.0}$} \\
\hline & & 1.2 & 2.6 & \\
\hline & \multicolumn{4}{|c|}{14 months } \\
\hline American beautyberry & $0 \mathrm{a}$ & $0 \mathrm{a}$ & $0 \mathrm{a}$ & $0 \mathrm{a}$ \\
\hline Blackjack oak & $0 \mathrm{a}$ & $85 \mathrm{j}-\mathrm{n}$ & $100 n$ & $100 n$ \\
\hline Post oak & $4 a b$ & $83 \mathrm{j}-\mathrm{n}$ & $100 n$ & $100 \mathrm{n}$ \\
\hline Tree huckleberry & 0 a & $60 \mathrm{fgh}$ & $63 \mathrm{f}-\mathrm{i}$ & $63 \mathrm{f}-\mathrm{i}$ \\
\hline Water oak & $--^{2}$ & $80 \mathrm{i}-\mathrm{m}$ & $79 \mathrm{~h}-1$ & $80 \mathrm{i}-\mathrm{m}$ \\
\hline \multirow[t]{2}{*}{ Yaupon } & $13 \mathrm{abc}$ & $31 \mathrm{~cd}$ & $63 \mathrm{f}-\mathrm{i}$ & $55 \mathrm{fg}$ \\
\hline & \multicolumn{4}{|c|}{26 months } \\
\hline American beautyberry & $3 a b$ & $2 \mathrm{a}$ & $0 \mathrm{a}$ & $2 \mathrm{a}$ \\
\hline Blackjack oak & $45 \mathrm{de}$ & $60 \mathrm{fgh}$ & $73 \mathrm{~g}-\mathrm{k}$ & $100 \mathrm{n}$ \\
\hline Post oak & 51 ef & $70 \mathrm{f}-\mathrm{k}$ & $94 \mathrm{l}-\mathrm{n}$ & $941-n$ \\
\hline Tree huckleberry & $0 \mathrm{a}$ & $0 \mathrm{a}$ & $0 \mathrm{a}$ & $0 \mathrm{a}$ \\
\hline Water oak & -2 & $80 \mathrm{i}-\mathrm{m}$ & $100 n$ & $100 n$ \\
\hline \multirow[t]{2}{*}{ Yaupon } & $22 \mathrm{bc}$ & $69 \mathrm{f}-\mathrm{k}$ & $87 \mathrm{k}-\mathrm{n}$ & $931-n$ \\
\hline & \multicolumn{4}{|c|}{36 months } \\
\hline American beautyberry & $0 \mathrm{a}$ & $0 \mathrm{a}$ & $0 \mathrm{a}$ & $0 \mathrm{a}$ \\
\hline Blackjack oak & $6 a b$ & $83 \mathrm{j}-\mathrm{n}$ & $99 \mathrm{mn}$ & $99 \mathrm{mn}$ \\
\hline Post oak & $8 \mathrm{ab}$ & $86 j-n$ & $99 \mathrm{mn}$ & $99 \mathrm{mn}$ \\
\hline Tree huckleberry & $0 \mathrm{a}$ & $3 \mathrm{ab}$ & $8 a b$ & $0 \mathrm{a}$ \\
\hline Water oak & -2 & $80 \mathrm{i}-\mathrm{m}$ & $99 \mathrm{mn}$ & $99 \mathrm{mn}$ \\
\hline Yaupon & $12 a b c$ & $30 \mathrm{~cd}$ & $62 \mathrm{f}-\mathrm{i}$ & $67 \mathrm{f}-\mathrm{j}$ \\
\hline
\end{tabular}

IMeans followed by the same letter are not significantly different at the $95 \%$ level according to Tukeu's $w$-procedure. Mean values for species in unt reated plots were $0 \mathrm{a}$ at all evaluation dates.

${ }^{2}$ Stands not adequate to allow evaluation.

\section{of the herbicide.}

Soils of the Marquez location averaged $83 \%$ sand content and contained only $5 \%$ clay to $90 \mathrm{~cm}$ deep. Organic matter content averaged only $0.63 \%$ and $\mathrm{pH}$ was 6.2 . Less than $13 \mathrm{~cm}$ of rainfall were received for 4 months after hexazinone application. However, responses of blackjack oak and post oak following hexazinone application near Marquez were similar to those observed in the experiment near College Station. By 26 months after treatment near Marquez, blackjack oak and post oak canopy reductions were grcater than $80 \%$ where $1.2 \mathrm{~kg} /$ ha of hexazinone were applied, and the canopies were eliminated where 2.6 or $5 \mathrm{~kg} /$ ha were applied (Table 3). Yaupon initially appeared somewhat more susceptible to the herbicide near Marquez (Table 3) than in the experiment near College Station (data not shown). However, by 36 months after application, response of yaupon was similar between experimental sites. Canopy reduction was $30 \%$ or less where 0.6 or $1.2 \mathrm{~kg} / \mathrm{ha}$ of hexazinone were applied, and only 62 and $67 \%$ where 2.6 and 5 $\mathrm{kg} / \mathrm{ha}$ were applied, respectively.

Based on limited observations, American elm appeared to be susceptible to hexazinone in the experiment near Marquez (defoliation $\geq 90 \%$ from $2.6 \mathrm{~kg}$ / ha of the herbicide). Trec hucklcberry were defoliated the growing season after hexazinone application, but had completely recovered from herbicidal effects after 26 mont hs (Table 3). Water oak canopy reduction was about $80 \%$ the year after treatment, regardless of hexazinone rate, somewhat less than in the experiment near College Station where it responded the same as blackjack oak and post oak. However, 2.6 and $5 \mathrm{~kg} / \mathrm{ha}$ of hexazinone had eliminated the water oak canopies by 26 months after herbicide application. American beautyberry was not effectively controlled by hexazinone, regardless of rate of application or date of evaluation (Table 3).

The general aspect at 36 months after application of 2.6 or 5 $\mathrm{kg}$ / ha of hexazinone near Marquez was excellent control of the oak overstory but only suppression of understory species, especially yaupon and American beautyberry. Although yaupon height appeared to have been reduced by about $50 \%$ and the stand thinned in density, it and American beautyberry (which filled any openings created by thinning the yaupon) formed essentially continuous cover on plots where the hexazinone had been applied.

Although grass standing crop in the experiment near College Station was increased by all hexazinone treatments after 18 months, greatest grass standing crop occurred where $4 \mathrm{~kg}$ / ha were applied (Table 4). Grass standing crop was highly variable at 27 months after hexazinone applications because of dry growing conditions, but there was a trend for increased grass standing crop where $1 \mathrm{~kg} /$ ha or more hexazinone was applied, compared to untreated plots. Brownseed paspalum accounted for more than $80 \%$ of the botanical composition, based on foliar cover, after 27 months on untreated plots and those receiving $0.5 \mathrm{~kg} / \mathrm{ha}$ of hexazinone. On plots treated with $1 \mathrm{~kg} /$ ha or more the herbicide, brownseed paspalum and common Bermudagrass (Cynodon dactylon) accounted for about $50 \%$ of the grass foliar cover with Arizona cottontop (Digitaria californica), little bluestem, King Ranch bluestem (Bothriochloa ischaemum), knotroot bristlegrass (Seta-

Table 4. Herbaceous standing crop (oven-dry) at various times after grid application of hexazinone at various rates on March 24, 1976, to thicketized Post Oak Savannah near College Station, Texas. ${ }^{1}$

\begin{tabular}{|c|c|c|c|c|c|}
\hline \multirow{3}{*}{$\begin{array}{l}\text { Application } \\
\text { rate } \\
(\mathrm{kg} / \mathrm{ha})\end{array}$} & \multirow{3}{*}{$\begin{array}{c}\text { Spacing } \\
(\mathrm{m})\end{array}$} & \multicolumn{4}{|c|}{ Standing crop $(\mathrm{kg} / \mathrm{ha})$} \\
\hline & & \multicolumn{2}{|c|}{18 months } & \multicolumn{2}{|c|}{27 months } \\
\hline & & Grasses & Forbs & Grasses & Forbs \\
\hline 0 & - & $918 a$ & $76 a$ & $365 a$ & $323 a$ \\
\hline 0.5 & 3 & $1282 \mathrm{~b}$ & $51 \mathrm{a}$ & $550 \mathrm{a}$ & $463 \mathrm{~b}$ \\
\hline 1 & 3 & $1365 \mathrm{~b}$ & $93 \mathrm{a}$ & $1180 \mathrm{~b}$ & $408 \mathrm{~b}$ \\
\hline 2 & 1.5 & $1282 \mathrm{~b}$ & $32 \mathrm{a}$ & $1100 \mathrm{~b}$ & $342 \mathrm{ab}$ \\
\hline 2 & 3 & $1543 \mathrm{bc}$ & $18 \mathrm{a}$ & $1214 \mathrm{~b}$ & $1091 \mathrm{c}$ \\
\hline 4 & 1.5 & $1985 \mathrm{c}$ & $92 \mathrm{a}$ & $1551 \mathrm{c}$ & $374 \mathrm{~b}$ \\
\hline
\end{tabular}

'Means within a column followed by the same letter are not significantly different at the $95 \%$ level according to Duncan's multiple range test. 
ria geniculata), beaked panicum (Panicum anceps), and threeawns (Aristida spp.) composing the bulk of the remaining foliar cover. Although the plots were not sampled the third and fourth growing seasons after hexazinone application, observations indicated the same trend in forage production that occurred after 18 months. Western ragweed (Ambrosia psilostachya) and western ironweed (Vernonia baldwinii) were the most common forbs, regardless of treatment, in the experiment near College Station.

The grass stand was extremely sparse, regardless of treatment, near Marquez the year after hexazinone application. Less than 80 $\mathrm{kg} /$ ha of standing grass crop were harvested from the untreated plots, and only 165 to $200 \mathrm{~kg}$ / ha from those treated with hexazinone (data not shown). Longleaf chasmanthium and dichantheliums accounted for the total grass standing crop, and the forb standing crop was insignificant (usually less than $5 \mathrm{~kg} / \mathrm{ha}$ ). Because of a lack of effective yaupon control on the Marquez site, standing crop did not increase, compared to the year after hexazinone treatment, for the duration of the study.

Bare areas, averaging $25 \mathrm{~cm}$ in diameter, were present at the point of herbicide deposition for a year after application of the hexazinone near College Station. Bare ground in unteated plots averaged $35 \%$ at 1 year after initiation of the study. Hexazinone application increased the percentage bare ground about $6 \%$ where $0.5 \mathrm{~kg} / \mathrm{ha}$ was applied, by $8 \%$ to $12 \%$ on plots receiving $1 \mathrm{~kg} / \mathrm{ha}$, by about $16 \%$ (3-m spacing) and $23 \%$ ( $1.5-\mathrm{m}$ spacing) where $2 \mathrm{~kg} / \mathrm{ha}$ were applied, and by $29 \%$ on plots treated with $4 \mathrm{~kg} / \mathrm{ha}$, compared to untreated plots. These bare spots were essentially covered by herbaceous vegetation, primarily common Bermudagrass and forbs, by 26 months after hexazinone application.

Based on these data, it appears that at least $2 \mathrm{~kg} / \mathrm{ha}$ (active ingredient) of hexazinone, applied as $15 \%$ spheres in a 1.5 to $3-\mathrm{m}$ grid pattern, are required for effective control of blackjack oak and post oak. However, potential range improvement from such applications will depend on the extent of the yaupon and American beautyberry cover associated with the oaks. On sites not supporting yaupon or with only scattered plants, there is potential for increased range forage production following oak control with hexazinone. However, a heavy yaupon and/or American beautyberry understory may negate the benefits of oak control with hexazinone.

\section{Literature Cited}

Gould, F.W. 1969. Texas Plants. A checklist and ecological summary. Texas Agr. Exp. Sta. MP-585. 121 p.

Meyer, R.E., and R.W. Bovey. 1980. Hexazinone and other herbicides on Texas woody plants. Weed Sci. 28:358-362.

Milford, M.H. 1975. Introduction to Soils and Soil Science. Laboratory exercises (2nd Ed.). Kendall and Hunt Publ. Co., Dubuque, Iowa. p. 11-18.

Mortensen, J.L. 1965. Partial extraction of organic matter p. 1401-1407. In: C.A. Black (Ed.). Methods of Soil Analysis. (Part II). Amer. Soc. Agron., Madison, Wis.

Peech, M. 1965. Hydrogen-ion activity. p. 920-921. In: C.A. Black (Ed.). Methods of Soil Analysis. (Part II). Amer. Soc. Agron., Madison, Wis.

Scifres, C.J. 1980. Brush Management. Principles and Practices for Texas and the Southwest. Texas A\&M Univ. Press, College Station. 360 p.

Scifres, C.J., and J.L. Mutz. 1978. Response of oaks and associated woody species to "Velpar." Proc. So. Weed Sci. Soc. (Abstr.) 31:214.

Scifres, C.J., and R.H. Haas. 1974. Vegetation changes in a post oak savannah following woody plant control. Texas Agr. Exp. Sta. MP1136. $11 \mathrm{p}$.

Scifres, C.J., J.L. Mutz, and C.H. Meadors. 1978. Response of range vegetation to grid placement and aerial application of karbutilate. Weed Sci. 26:139-144.

Steel, R.G.D., and J.H. Torrie. 1960. Principles and Procedures of Statistics. McGraw-Hill Book Co., Inc. New York. 481 p.

\section{Membership in the Society for Range Management. . .}

is open to those engaged in or interested in the study. management, or use of range ecosystems and the intelligent use of all range resources

includes research scientists, ranchers. govemmental agency administrators and technical personnel. teachers, students, and people from the business community

provides members with two publications-one oriented to research (Journal of Range Management) and the other oriented to practical resource manogement (Rangelands) offers opportunities for face-to-face exchange of ideas of local, national, and international meetings of the Society.

Dues vary according to type of membership and geographical section. For application forms and additional information, contact the:

Executive Secretary

Society for Range Mangoement

2760 West Fifth Avenue

Denver. Colorado 80204

(303) 571-0174 